\title{
Invasion by Solidago species has limited impacts on soil seed bank communities
}

\author{
Dominika Kundel, Mark van Kleunen, Wayne Dawson* \\ Ecology, Department of Biology, University of Konstanz, Universitaetsstrasse 10, Konstanz D 78457, Germany
}

\begin{abstract}
Increasing attention in invasion biology is being paid to measuring and understanding the impacts of invasive species. For plant invasions, however, the impact of invasion on soil seed bank communities has been under-studied. At six sites in southern Germany, we investigated whether areas invaded by Solidago gigantea and Solidago canadensis experienced a reduction in seed bank species richness, size and diversity, and a change in species composition compared to adjacent uninvaded areas. We found no overall effect of invasion on seed bank size, or on species richness and diversity. Seed bank size significantly decreased from $0-5 \mathrm{~cm}$ to $5-10 \mathrm{~cm}$ depth in both invaded and uninvaded areas. A significant amount of variation in species composition was explained by invasion, but it was only one-tenth of that explained solely by site effects. Our study suggests that invasion by Solidago species may not have the same impacts on the soil seed banks of native species as other invasive perennial forbs that have so far been studied.
\end{abstract}

\section{Zusammenfassung}

In der Invasionbiologie wird dieserzeit vermehrtes Augenmerk darauf gerichtet, die Auswirkungen invasiver Pflanzenarten besser einzuschätzen und verstehen zu können. Welche Auswirkungen invasive Pflanzenarten auf die Samenbanken von Pflanzengemeinschaften haben, wurde in diesem Kontext bisher allerdings nur unzureichend untersucht. Im Süden Deutschlands wurde an sechs Standorten unterschiedlicher Habitattypen untersucht, ob Samenbanken durch die Invasion von Solidago gigantea und S. canadensis eine Reduktion des Artenreichtums, der Größe oder der Diversität erfuhren und auch, ob sich die Artenzusammensetzung innerhalb der Samenbanken durch die Invasion veränderte. Die Samenbanken der invadierten Standorte wurden hierfür mit angrenzenden, nicht-invasierten Standorten verglichen. Insgesamt zeigte die Invasion keinen Effekt auf die Größe der Samenbanken, den Artenreichtum oder die Artenvielfalt. Sowohl in invasierten als auch nicht-invasierten Standorten nahm die Größe der Samenbanken mit zunehmender Tiefe von 0-5 cm zu 5-10 cm signifikant ab. Ein signifikanter Anteil der Variation in der Artenzusammensetzung konnte durch die Invasion erklärt werden, ein Zehntel hiervon allerdings wurde durch Standorteffekte bedingt. Unsere Studie deutet darauf hin, dass die Invasion von Solidago Arten nicht die gleichen Auswirkungen auf die Samenbanken einheimischer Arten haben wie die anderen invasiven mehrjährigen Stauden, die bisher untersucht worden sind.

Keywords: Legacy effect; Exotic; Goldenrod; Invasive species

*Corresponding author. Tel.: +49 753188 2116; fax: +49 7531883430 .

E-mail address: wayne.dawson@uni-konstanz.de (W. Dawson). 


\section{Introduction}

Recently, increasing focus in invasive-plant ecology has been given to identifying and measuring the impacts of invasive plants on native plant species and ecological processes (Davis et al., 2011; Vila et al., 2011). A large number of invasive-plant impact studies have focused on the effects of invasion on native plant species abundance, richness and diversity, with overall negative effects shown across multiple taxa (Vila et al., 2011), presumably as a consequence of competition and suppression by the alien species. While multiple studies have considered impacts of invasive plants on native plant diversity and composition aboveground, relatively few studies have focused on the indirect impact of invasive plants on native species through changes in soil seed banks (Gioria, Pyšek, \& Moravcova, 2012), despite their ecological importance (Thompson, Bakker, \& Bekker, 1997). Restoration efforts after invasive species removal may require additional seed input if seed banks are depleted or strongly different in species composition.

Invasive species may impact soil seed banks via several potential mechanisms. Many invasive plants form tall, dense stands that may restrict the suite of species able to survive, grow and produce seeds under high shade. They may also act as strong physical barriers to seed dispersal into seed banks. Allelopathy (del Fabbro, Güsewell, \& Prati, 2014), changes in organic matter deposition, soil moisture and nutrient content and rates of decomposition (Dassonville et al., 2008; Scharfy, Eggenschwiler, Venterink, Edwards, \& Güsewell, 2009) can occur in soils of invaded habitats, which may lead to an increased rate of viable seed loss from seed banks.

Solidago canadensis and Solidago gigantea are two invasive and now widespread alien species occurring throughout Europe, often in near-monospecific stands in a variety of habitats. Despite being well-known invaders, we are aware of no study that has assessed the effects of Solidago on seed bank diversity and composition in invaded areas. We assessed abundance, species richness, diversity and composition in soil seed banks under areas invaded by $S$. gigantea and $S$. canadensis, and compared them to soil seed banks in adjacent uninvaded areas of vegetation. Our main hypotheses were:

(1) The abundance, richness and diversity of species in the soil seed bank will be reduced in invaded areas compared to uninvaded areas.

(2) The composition of species in the soil seed bank will differ in areas invaded by Solidago spp., compared to areas uninvaded.

(3) Soils from invaded areas will have a greater Solidago abundance than uninvaded areas. If persistent viable seed banks are not formed, then Solidago abundance should decline strongly with increasing soil depth (with increasing depth acting as a surrogate for increasing soil age). We had no a priori expectations regarding how the effects of invasion on native species seed banks might be affected by soil depth.

\section{Material and methods}

\section{Study sites and soil collection}

Six sites were chosen for soil collection from areas of vegetation that were either invaded or uninvaded by Solidago species in the vicinity of the city of Constance in Baden-Württemberg, Southern Germany (Table 1). The oldest herbarium record for S. gigantea in Germany dates to the first half of the 19th century, while $S$. canadensis was first recorded in 1857, and both species are now widespread in the Central Europe (Weber 1998; Weber \& Jakobs 2005). Both $S$. gigantea and $S$. canadensis are known to be tolerant of a broad range of habitat types, and S. gigantea in particular is known to invade habitats with wetter soils (Sebald, Seybold, Philippi, \& Woerz, 1996; Werner, Bradbury, \& Gross, 1980). Thus, the six sites were chosen to reflect a range of habitat types where $S$. gigantea (all six sites) and $S$. canadensis (two of the sites) have invaded, including wet meadows with tall native herbs, Carex spp. and Phragmites australis, and anthropogenic habitats (Table 1).

In April 2013, soil samples were obtained from the six sites. At each site, an area of vegetation invaded by Solidago, and an adjacent uninvaded area were identified. The invaded areas were clearly distinguishable, due to the presence of dead Solidago aboveground biomass from the previous year and emerging new shoots. Spatial proximity of invaded and uninvaded areas should minimise differences in environmental conditions due to factors other than invasion. At each site, the invaded patches were all larger than $50 \mathrm{~m}^{2}$, and five out of six sites had invaded patches $>100 \mathrm{~m}^{2}$. The maximum distance between an invaded and uninvaded quadrat was $\sim 50 \mathrm{~m}$. Seed banks were sampled in each invaded and uninvaded area per site, within three, evenly spaced (5-10 m distance) replicate quadrats $(2 \mathrm{~m} \times 2 \mathrm{~m})$. The quadrats were systematically placed in order to obtain a representative set of soil seed bank samples across each invaded and uninvaded area. Within each quadrat, five replicate soil cores of $10 \mathrm{~cm}$ depth were taken, using a $5 \mathrm{~cm}$ diameter soil-corer. The five samples were taken from close to each corner and from the centre of each quadrat in order to capture small-scale spatial variability that is common in soil seed banks. The soil cores were split in situ into two depths: $0-5 \mathrm{~cm}$ and $5-10 \mathrm{~cm}$ depth, so that we could assess variation in Solidago and non-Solidago species abundance, and species composition according to soil depth. The five core samples of each depth within a quadrat were bulked. Thus, with six sites, we obtained a total of 36 soil seed bank samples overall and per soil depth (six sites $\times$ two (invaded and uninvaded areas per site) $\times$ three quadrats per invaded/uninvaded area within a site). The soil samples were stored at $6^{\circ} \mathrm{C}$ until all samples were collected ( $\leq 3$ days). 
Table 1. Locations and descriptions of the six sites near Constance, Germany, from which soil seed bank samples were taken of areas not invaded and invaded by Solidago gigantea/Solidago canadensis. A list of other plant species observed per site is provided in Appendix A.

\begin{tabular}{|c|c|c|c|c|c|}
\hline & Location & $\begin{array}{l}\text { Position } \\
\text { (latitude, } \\
\text { longitude) }\end{array}$ & Habitat type & $\begin{array}{l}\text { Solidago species } \\
\text { present }\end{array}$ & $\begin{array}{l}\text { Other common species } \\
\text { present }\end{array}$ \\
\hline A & $\begin{array}{l}\text { University } \\
\text { campus park, } \\
\text { Constance }\end{array}$ & $\begin{array}{l}47^{\circ} 41^{\prime} 13.9^{\prime \prime} \mathrm{N}, \\
9^{\circ} 11^{\prime} 20.1^{\prime \prime} \mathrm{E}\end{array}$ & Tall-herb fen & S. gigantea & $\begin{array}{l}\text { Filipendula ulmaria, } \\
\text { Juncus spp. }\end{array}$ \\
\hline B & $\begin{array}{l}\text { Wollmatingerstrasse, } \\
\text { Constance }\end{array}$ & $\begin{array}{l}47^{\circ} 41^{\prime} 17.5^{\prime \prime} \mathrm{N} \\
9^{\circ} 10^{\prime} 16.6^{\prime \prime} \mathrm{E}\end{array}$ & $\begin{array}{l}\text { Grassland roadside } \\
\text { verge }\end{array}$ & $\begin{array}{l}\text { S. gigantea, } S . \\
\text { canadensis }\end{array}$ & $\begin{array}{l}\text { Arrhenatherum elatius, } \\
\text { Cirsium oleraceum, Poa } \\
\text { pratensis }\end{array}$ \\
\hline $\mathrm{C}$ & Allensbach & $\begin{array}{l}47^{\circ} 43^{\prime} 46.0^{\prime \prime} \mathrm{N}, \\
9^{\circ} 3^{\prime} 39.7^{\prime \prime} \mathrm{E}\end{array}$ & $\begin{array}{l}\text { Sedge/reed } \\
\text { dominated wet } \\
\text { meadow }\end{array}$ & S. gigantea & $\begin{array}{l}\text { Carex acutiformis, } \\
\text { Phragmites australis }\end{array}$ \\
\hline D & Dettingen & $\begin{array}{l}47^{\circ} 43^{\prime} 40.1^{\prime \prime} \mathrm{N}, \\
9^{\circ} 7^{\prime} 13.7^{\prime \prime} \mathrm{E}\end{array}$ & $\begin{array}{l}\text { Grassland/scrub on } \\
\text { a forest edge }\end{array}$ & S. gigantea & $\begin{array}{l}\text { Poa pratensis, Rubus } \\
\text { fruticosus agg., Urtica } \\
\text { dioica }\end{array}$ \\
\hline $\mathrm{E}$ & Dettingen & $\begin{array}{l}47^{\circ} 43^{\prime} 34.3^{\prime \prime} \mathrm{N} \\
9^{\circ} 7^{\prime} 36.5^{\prime \prime} \mathrm{E}\end{array}$ & Wet grassland & S. gigantea & $\begin{array}{l}\text { Arrhenatherumelatius, } \\
\text { Ranunculus acris, Urtica } \\
\text { dioica }\end{array}$ \\
\hline $\mathrm{F}$ & $\begin{array}{l}\text { Constance } \\
\text { industrial area }\end{array}$ & $\begin{array}{l}47^{\circ} 40^{\prime} 25.2^{\prime \prime} \mathrm{N} \\
9^{\circ} 9^{\prime} 20.1^{\prime \prime} \mathrm{E}\end{array}$ & $\begin{array}{l}\text { Grassland/scrub on } \\
\text { abandoned } \\
\text { industrial ground }\end{array}$ & $\begin{array}{l}\text { S. gigantea, } S \text {. } \\
\text { canadensis }\end{array}$ & $\begin{array}{l}\text { Aster novi-belgii, Cornus } \\
\text { sanguinea, Potentilla } \\
\text { reptans }\end{array}$ \\
\hline
\end{tabular}

\section{Soil seed bank assessment}

Once all soil samples were obtained, they were partially broken up and air-dried for $24 \mathrm{~h}$, to facilitate sieving. Then, each sample was sieved twice using a $5 \mathrm{~mm}$ mesh, to remove coarse material, and to obtain a finer, spreadable soil. Care was taken to remove soil attached to the sieve for each sample, and the sieve was thoroughly cleaned between samples. Seedling trays $(48 \mathrm{~cm} \times 33 \mathrm{~cm} \times 6.5 \mathrm{~cm})$ were filled with a 1:1 sand-vermiculite mixture onto which the sieved samples were thinly spread ( $\sim 5 \mathrm{~mm}$ depth). One tray was used per quadrat, and the tray was split into two halves with a rigid plastic root barrier. One half of each tray was used for the $0-5 \mathrm{~cm}$ depth sample, and the other half for the $5-10 \mathrm{~cm}$ sample. Each tray was then placed in a larger tray, acting as a water reservoir, and was covered with a transparent plastic propagator lid. The 36 trays were randomly positioned on a bench in a $4 \times 9$ configuration in a greenhouse, which was heated to $18^{\circ} \mathrm{C}$ during night and $20^{\circ} \mathrm{C}$ during daytime; these temperatures lie within the range shown to be optimal for germination of a wide range of species from temperate European soil seed banks (Thompson \& Grime 1979). The propagator lids were removed 12 days after the assessment began, and after four weeks, trays were re-randomized. The assessment period lasted for nine weeks; after five weeks, the seedlings were given fertiliser on a weekly basis to increase growth rates, and therefore make species identification possible. To stimulate further germination from week six onwards, extra light was supplied for $3 \mathrm{~h}$ in the morning (6-9 am) and $2 \mathrm{~h}$ in the evening $(6-8 \mathrm{pm})$.
Four weeks after starting the experiment, the first seedlings identifiable as species were removed from the trays. To avoid misidentification, only seedlings that had at least developed two true leaves were removed. At this developmental stage it was possible to draw a clear distinction between different morphospecies. Up to four plants per species were transplanted into a $1.4 \mathrm{~L}$ pot, with plants from different trays kept separately. Once a species was identifiable, all plants of this species were counted and removed from the trays. After nine weeks, any unidentified plants remained assigned as morphospecies and the assessment ceased.

\section{Analyses}

We used linear mixed models in the R package 'Ime4' (Bates, Maechler, Bolker, \& Walker, 2014) in order to analyse (i) the effect of soil depth and invasion on total number of individual plants, the total species richness and diversity (all excluding Solidago) emerging from the seed banks, and (ii) the total number of Solidago individuals emerging from the seed bank. Total number of individuals (non-Solidago and Solidago species), and species richness were $\ln (x+1)$ transformed prior to analysis. For diversity, the Shannon diversity index was calculated per soil depth per quadrat. Each site consisted of an invaded and an uninvaded patch, and there were three quadrats within each patch. Thus, the random effects included site, patch nested within site, and quadrat nested within patch within site, while fixed effects included invasion status, initially in a two-way interaction with soil depth. Significance of two-way interactions and main effects was 
assessed using Type III ANOVA in the R package 'lmerTest' (Kuznetsova, Brockhodd, \& Christensen, 2013).

We used permutational analysis of variance (PERMANOVA) to assess the significance of variation in species composition explained by (i) Solidago invasion (communities pooled across soil depths), (ii) Solidago invasion for each soil depth individually, and (iii) site (communities pooled across soil depths). To assess the significance of invasion across soil depths, we combined soil subsamples for each depth per quadrat, and calculated a Gower dissimilarity matrix with the 36 samples. Species abundances were fourth-root transformed prior to computing the dissimilarity matrix, as this increases the contributions of rarer species in calculating dissimilarity between communities (Clarke 1993). The PERMANOVA was then performed (with 9999 permutations), including 'invasion' as a fixed effect, and 'site' as a random effect. The analysis was repeated for each depth individually. For the significance of site, the PERMANOVA was performed on the seed bank samples pooled across depths, with site as a fixed effect. The PERMANOVAs were performed using the function 'adonis' in the package 'vegan' (Oksanen et al., 2013) in the R program version 3.0.2 (R Core Team 2013). Prior to each analysis, we tested for variation in dispersion in species composition among the fixed and random effect levels involved, using the function 'betadisper' in 'vegan'. A significant amount of variation in dispersion between invasion statuses or among sites could explain any significant variation detected in species composition. Two of the sites (B and F, Table 1), included both $S$. canadensis and $S$. gigantea. To assess the effect of invasion by $S$. gigantea only, we also conducted the analyses above with the four sites that contained $S$. gigantea only (sites A, C, D and E, Table 1). We used non-metric multidimensional scaling in order to produce reduced-space 2-D plots representing variation in species composition according to invasion, site and depth (using 'metaMDS' in 'vegan').

(B)

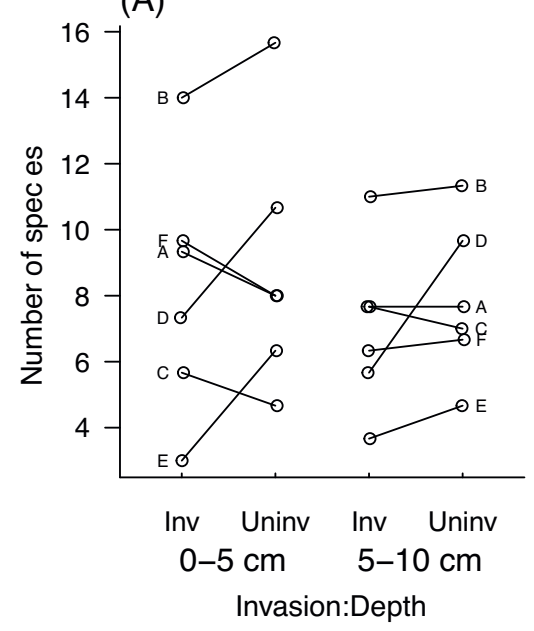

(C)

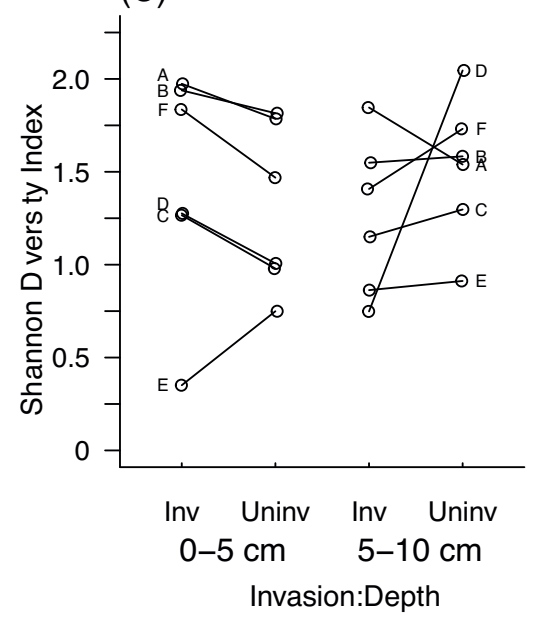

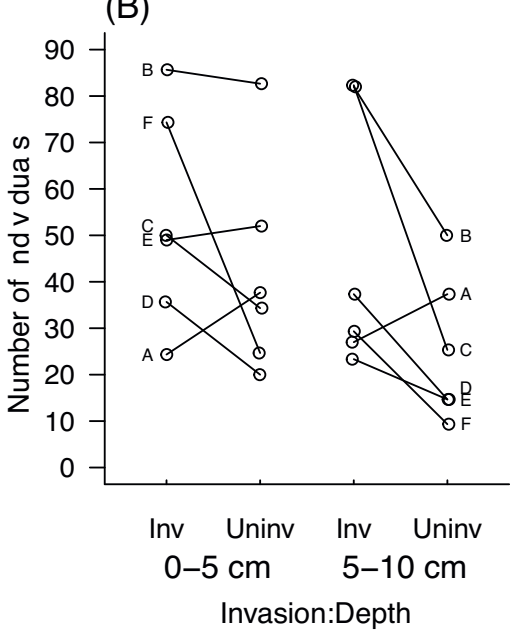

(D)

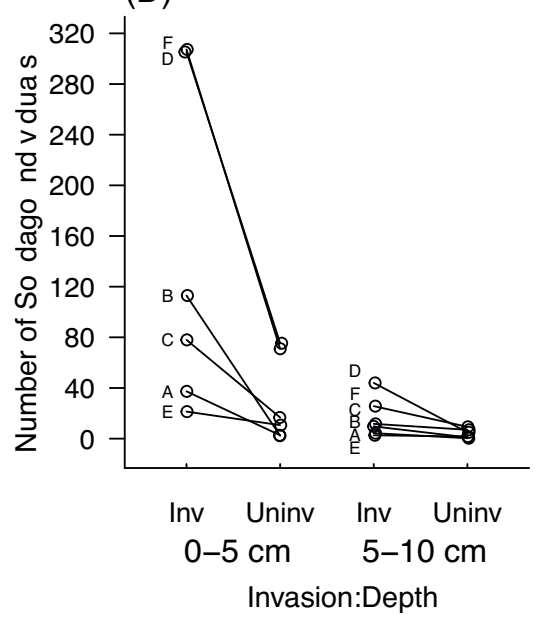

Fig. 1. Mean number of non-Solidago plants (A), species richness (B), diversity (C) and Solidago abundance (D) emerging from seed banks of invaded ('Inv') and neighbouring uninvaded ('Uninv') areas at 0-5 and 5-10 cm depth, from six sites (A-F, see Table 1) near Constance, Germany. 
Table 2. Analysis of variance summaries for linear mixed models, testing the variation in species richness, seedling abundance, diversity and Solidago abundance in seed banks that is explained by invasion, soil depth and their interaction. Denominator degrees of freedom are calculated using the Kenward-Roger approximation. Analyses were also done for the four sites only containing S. gigantea.

\begin{tabular}{|c|c|c|c|c|c|c|c|c|}
\hline & \multicolumn{4}{|c|}{ All sites $(n=6)$} & \multicolumn{4}{|c|}{ Sites with only $S$. gigantea $(n=4)$} \\
\hline & $\mathrm{df}$ & MS & $\mathrm{F}$ & $\mathrm{P}$ & df & MS & $\mathrm{F}$ & $\mathrm{P}$ \\
\hline \multicolumn{9}{|c|}{ Species richness } \\
\hline Invasion & 1,5 & 0.126 & 1.16 & 0.330 & 1,3 & 0.170 & 1.332 & 0.332 \\
\hline Soil depth & 1,34 & 0.102 & 0.94 & 0.339 & 1,22 & 0.007 & 0.058 & 0.812 \\
\hline $\mathrm{I} \times \mathrm{S}$ & 1,34 & 0.005 & 0.05 & 0.830 & 1,22 & $<0.001$ & 0.002 & 0.962 \\
\hline \multicolumn{9}{|l|}{ Abundance } \\
\hline Invasion & 1,5 & 0.304 & 1.98 & 0.218 & 1,3 & 0.027 & 0.196 & 0.688 \\
\hline Soil depth & 1,34 & 1.889 & 12.21 & 0.001 & 1,22 & 0.365 & 2.662 & 0.117 \\
\hline $\mathrm{I} \times \mathrm{S}$ & 1,34 & 0.621 & 4.01 & 0.053 & 1,22 & 0.626 & 4.568 & 0.044 \\
\hline \multicolumn{9}{|l|}{ Diversity } \\
\hline Invasion & 1,5 & 0.020 & 0.09 & 0.775 & 1,3 & 0.044 & 0.148 & 0.727 \\
\hline Soil depth & 1,34 & 0.007 & 0.03 & 0.865 & 1,22 & 0.193 & 0.642 & 0.432 \\
\hline $\mathrm{I} \times \mathrm{S}$ & 1,34 & 0.709 & 3.18 & 0.083 & 1,22 & 0.441 & 1.468 & 0.239 \\
\hline \multicolumn{9}{|c|}{ Solidago abundance } \\
\hline Invasion & 1,5 & 8.749 & 26.60 & 0.004 & 1,3 & 3.516 & 16.07 & 0.028 \\
\hline Soil depth & 1,34 & 55.791 & 169.62 & $<0.001$ & 1,22 & 33.55 & 153.62 & $<0.001$ \\
\hline $\mathrm{I} \times \mathrm{S}$ & 1,34 & 1.677 & 5.10 & 0.030 & 1,22 & 0.572 & 2.614 & 0.120 \\
\hline
\end{tabular}

\section{Results}

Across all samples, 6499 individual plants emerged from the soil seed banks, representing 100 species. More than half of these plants (3490) were of Solidago species. Of the remaining 3009 plants, the most abundant species was Juncus effusus (492), followed by Urtica dioica (448), Scrophularia umbrosa (316) and Hypericum perforatum (221). The identity of all species found in the seed banks is given in Appendix A.

\section{Species richness, abundance and diversity}

Species richness of soil seed banks varied greatly among sites, as did differences between soil depths and invaded and non-invaded areas (Fig. 1A); there was no significant interaction between soil depth and invasion across sites, and no significant effect of depth or invasion overall (Table 2). This was also the case when sites only including $S$. gigantea were considered (Table 2). Across sites, there was a tendency for abundance of plants emerging from seed banks (excluding Solidago) to be more strongly reduced in uninvaded versus invaded areas at a depth of $5-10 \mathrm{~cm}$, compared to $0-5 \mathrm{~cm}$ depth (Fig. 1B), but the significance of this interaction was marginal (Table 2). The interaction between invasion and soil depth was weakly significant for the four sites only including $S$. gigantea (Table 2), with greater seedling abundance at $0-5 \mathrm{~cm}$ depth (mean per quadrat per site $=36 \pm 6.6)$ than $5-10 \mathrm{~cm}$ depth $(23 \pm 5.4$ seedlings $)$ for uninvaded areas. In invaded areas, there was little difference in non-Solidago seedling abundance between $0-5 \mathrm{~cm}$ depth
$($ mean $=39.8 \pm 6.1)$ and $5-10 \mathrm{~cm}$ depth (mean $42.5 \pm 13.6)$. Across invaded and uninvaded areas, there was a significant reduction in plant abundance with increasing soil depth when all sites were considered, but not when the four sites with only $S$. gigantea were included (Table 2). There was no significant overall effect of invasion on plant abundance in soil seed banks (Table 2). Differences in seed bank diversity between uninvaded and invaded areas were not significantly dependent upon soil depth (Table 2; Fig. 1C). Overall, there was no significant effect of soil depth or invasion by Solidago on diversity (Table 2). Results were similar when sites with only $S$. gigantea were included (Table 2).

The abundance of Solidago plants was strongly reduced in uninvaded compared to invaded soils of $0-5 \mathrm{~cm}$ depth, and the reduction was less pronounced for soils of $5-10 \mathrm{~cm}$ depth (Fig. 1D; significant interaction between soil depth and invasion, Table 2), because invaded soils at $5-10 \mathrm{~cm}$ depth also had far fewer Solidago plants (Fig. 1D, significant main effect of depth, Table 2). Across both soil depths, significantly more Solidago plants emerged from invaded soils (mean per quadrat per site $=80 \pm 29.5$ seedlings) compared to uninvaded soils (mean per quadrat per site $=16.9 \pm 7.5$ seedlings) (Table 2). When sites with $S$. gigantea only were considered, the significant interaction between soil depth and invasion was lost, while the main effects of invasion and soil depth remained significant (Table 2). Focusing on $S$. gigantea sites probably led to changes in the significance of invasion, depth and their interaction for Solidago and non-Solidago seedling abundance due to the loss of site F, which showed strong declines in seedling abundance between invaded and uninvaded areas (Fig. 1B and D). 
Table 3. Permutational analysis of variance summaries assessing the amount of variation in seed bank species composition explained by Solidago invasion, for pooled depths and $0-5 \mathrm{~cm}$ and $5-10 \mathrm{~cm}$ depths separately (site was included as a random effect). Analyses were also done for the four sites only containing $S$. gigantea.

\begin{tabular}{|c|c|c|c|c|c|c|c|c|c|c|}
\hline & \multicolumn{5}{|c|}{ All sites $(n=6)$} & \multicolumn{5}{|c|}{ Sites with only $S$. gigantea $(n=4)$} \\
\hline & df & SS & MS & $\mathrm{F}$ & $\mathrm{P}$ & df & SS & MS & $\mathrm{F}$ & $\mathrm{P}$ \\
\hline \multicolumn{11}{|c|}{ Pooled soil } \\
\hline Invasion & 1 & 0.015 & 0.015 & 1.215 & 0.009 & 1 & 0.010 & 0.010 & 1.000 & 0.069 \\
\hline Residuals & 34 & 0.430 & 0.013 & & & 22 & 0.213 & 0.010 & & \\
\hline \multicolumn{11}{|c|}{$0-5 \mathrm{~cm}$ depth } \\
\hline Invasion & 1 & 0.014 & 0.014 & 1.505 & $<0.001$ & 1 & 0.007 & 0.007 & 1.150 & 0.023 \\
\hline Residuals & 34 & 0.306 & 0.009 & & & 22 & 0.131 & 0.006 & & \\
\hline \multicolumn{11}{|c|}{$5-10 \mathrm{~cm}$ depth } \\
\hline Invasion & 1 & 0.015 & 0.015 & 1.416 & 0.002 & 1 & 0.008 & 0.008 & 0.761 & 0.423 \\
\hline Residuals & 34 & 0.368 & 0.011 & & & 22 & 0.218 & 0.010 & & \\
\hline
\end{tabular}

\section{Species composition}

Across the two soil depths, a significant amount of variation in species composition was explained by invasion when accounting for site (Table 3). However, the amount of variation explained by invasion was small $(\sim 4 \%)$, and an order of magnitude smaller than the total amount of variation explained by site ( $\sim 40 \%$; Appendix B, Table 1$)$. The results were similar for both soil depths when they were considered individually (Table 3; Appendix B, Table 1). There was no significant variation in dispersion among seed bank communities according to invasion, but there was according site (see Appendix B, Table 2). The effect of invasion was also weaker when only the four sites including $S$. gigantea were considered (Table 3 ). There appeared to be no common change or convergence in seed bank species composition in invaded areas compared to uninvaded areas (see Appendix B, Fig. 1); the species responsible for the small differences in species composition in invaded versus uninvaded areas were site-dependent (Table 4).

\section{Discussion}

Among the few studies assessing effects of plant invasions on soil seed bank communities, effects of reduced abundance

Table 4. Total number of plants emerging from seed banks obtained from invaded and uninvaded areas in sites A-F (corresponding to panels A-F) for the 20 most common, non-Solidago species across the whole study (representing $\sim 80 \%$ of all individual plants emerged).

\begin{tabular}{|c|c|c|c|c|c|c|c|c|c|c|c|c|}
\hline \multirow[t]{2}{*}{ Species } & \multicolumn{6}{|c|}{ Invaded } & \multicolumn{6}{|c|}{ Uninvaded } \\
\hline & A & B & $\mathrm{C}$ & $\mathrm{D}$ & $\mathrm{E}$ & $\mathrm{F}$ & A & B & $\mathrm{C}$ & $\mathrm{D}$ & $\mathrm{E}$ & $\mathrm{F}$ \\
\hline Agrostis capillaris & 0 & 1 & 3 & 9 & 0 & 0 & 0 & 5 & 1 & 21 & 3 & 7 \\
\hline Aster novi-belgii & 0 & 0 & 0 & 0 & 0 & 28 & 0 & 0 & 0 & 0 & 0 & 21 \\
\hline Carex hirta & 5 & 31 & 21 & 0 & 2 & 49 & 0 & 4 & 10 & 0 & 0 & 15 \\
\hline Carex palescens & 0 & 0 & 0 & 0 & 0 & 0 & 0 & 25 & 0 & 0 & 0 & 0 \\
\hline Chenopodium polyspermum & 1 & 0 & 4 & 160 & 17 & 0 & 0 & 2 & 3 & 3 & 5 & 0 \\
\hline Erigeron annuus & 0 & 0 & 0 & 0 & 0 & 9 & 0 & 0 & 0 & 0 & 0 & 14 \\
\hline Eupatorium cannabinum & 0 & 0 & 28 & 0 & 1 & 0 & 0 & 0 & 26 & 2 & 19 & 0 \\
\hline Filipendula ulmaria & 0 & 2 & 0 & 0 & 0 & 0 & 26 & 4 & 0 & 0 & 0 & 0 \\
\hline Hypericum perforatum & 37 & 22 & 0 & 0 & 0 & 79 & 53 & 22 & 1 & 7 & 0 & 0 \\
\hline Juncus acutiformis & 7 & 35 & 0 & 2 & 0 & 1 & 4 & 6 & 0 & 1 & 0 & 0 \\
\hline Juncus effusus & 9 & 262 & 0 & 1 & 2 & 1 & 0 & 208 & 8 & 0 & 0 & 1 \\
\hline Juncus subnodulosus & 32 & 0 & 0 & 1 & 0 & 0 & 19 & 0 & 0 & 1 & 0 & 0 \\
\hline Juncus tenuis & 0 & 33 & 0 & 0 & 0 & 0 & 0 & 2 & 0 & 0 & 0 & 4 \\
\hline Lysimachia vulgaris & 2 & 20 & 6 & 0 & 0 & 0 & 11 & 34 & 15 & 0 & 0 & 0 \\
\hline Lythrum salicaria & 14 & 38 & 3 & 2 & 0 & 0 & 67 & 23 & 0 & 1 & 0 & 0 \\
\hline Oenothera biennis & 0 & 0 & 0 & 0 & 0 & 15 & 0 & 0 & 0 & 0 & 0 & 9 \\
\hline Plantago major & 0 & 3 & 0 & 0 & 0 & 3 & 0 & 11 & 0 & 2 & 2 & 2 \\
\hline Роа аппиа & 27 & 3 & 0 & 1 & 0 & 4 & 21 & 0 & 0 & 6 & 3 & 1 \\
\hline Scrophularia umbrosa & 2 & 6 & 302 & 0 & 0 & 0 & 0 & 1 & 5 & 0 & 0 & 0 \\
\hline Urtica dioica & 0 & 12 & 5 & 1 & 185 & 0 & 0 & 0 & 94 & 2 & 149 & 0 \\
\hline
\end{tabular}


and species richness, and changed species composition are in the majority (Gioria, Pyšek, \& Moravcova, 2012). In contrast, we found no significant reduction in soil seed bank species richness, abundance or diversity in areas invaded by Solidago compared to uninvaded areas. There was a tendency for total seed bank size to be lower in uninvaded compared to invaded sites, at greater soil depth (Fig. 1B), which could be due to greater immediate germination rates in uninvaded areas, which depletes the soil seed bank. del Fabbro et al. (2014) found greater seed bank germination rates from S. giganteainvaded soils compared to uninvaded soils, and suggested this may be due to chemical suppression of germination by $S$. gigantea. However, the significant amount of variation in species composition at both $0-5 \mathrm{~cm}$ and $5-10 \mathrm{~cm}$ depth explained by invasion while accounting for site was $4 \%$. This was more than an order of magnitude less than the variation explained by site differences ( $40 \%$; see Appendix B, Table 1). Thus, the effects of Solidago species (especially S. gigantea) on soil seed bank communities seem minor compared to other large, invasive herbaceous species in Europe that have been studied so far (Gioria \& Osborne 2010). The idiosyncratic shifts in species composition of invaded seed banks imply that invasion effects probably differed according to species-composition differences per se among sites.

One obvious reason why Solidago invasion had only small effects on seed bank community composition is that the areas invaded by Solidago spp. may have been invaded for a short time period. Strong differences in species composition between seed banks of uninvaded and invaded areas probably occur because of loss of species' seeds that do not remain viable for long in the soil, and are no longer replaced due to the absence of outcompeted, native reproducing plants. This leaves behind a subset of more persistent species' seeds capable of long periods of dormancy, such as Juncus spp., Carex spp. and Chenopodium polyspermum (Thompson et al. 1997). All sites have been invaded for an absolute minimum of three years, and one site (B) is known to have been invaded for at least 40 years (Hellmann, pers. comm.). Some species known to have more persistent seeds were more abundant in invaded than uninvaded neighbouring areas, and such patterns may explain the slight shifts in seed bank composition observed. For example, Juncus spp. in sites A and B, C. polyspermum in site D and Carex hirta especially in site F, were more abundant in invaded than uninvaded soils (Table 4). These species might either grow more abundantly in invaded areas or, as mentioned above, seeds germinate and are therefore lost from the seed bank more readily in uninvaded areas.

The minor effect of Solidago invasion on seed bank communities compared to other invasive species such as Heracleum mantegazzianum, Fallopia japonica and Gunnera tinctoria (Gioria \& Osborne 2010), may also result from the very different architecture of Solidago spp. Both G. tinctoria and $H$. mantegazzianum have large, rigid leaves that can shield large areas of ground from incoming seed rain, as well as shade out native species below and preventing seed production. F. japonica forms a dense, arching canopy that would also provide strong shading and acts as a barrier to incoming seed rain. In contrast, Solidago species form dense stands of vegetative growth but do not have large leaves, and may allow a greater amount of seed rain to reach the soil. In addition, native plant species richness has been shown to decrease by an average of $50 \%$ in areas invaded by Solidago canadensis compared to uninvaded areas (de Groot, Kleijn, \& Jogan, 2007), suggesting that persistence of a subset of potentially reproducing native species is possible. Furthermore, Solidago dominance in invaded areas may not be static over time, which would allow native species to grow, reproduce and replenish seed banks.

For Solidago, large numbers of seeds were present in the top $0-5 \mathrm{~cm}$ layer of soil of invaded sites (mean per quadrat per site $=16,568 \pm 6490 \mathrm{~m}^{-2}$ ). Even though numbers were greatly reduced by an order of magnitude at 5-10 cm depth (mean per quadrat per site $=1883 \pm 795 \mathrm{~m}^{-2}$ ), Solidago was still the most common species in the invaded seed bank at this depth $(\sim 25 \%$ of all plants were Solidago from 5 to $10 \mathrm{~cm}$ depth soils across all sites). These numbers are probably underestimates of the total seed abundance, as $S$. gigantea is known to chemically suppress germination of its own seeds (Weber \& Jakobs 2005). Assuming that depth is a surrogate for soil (and therefore seed) age, the sheer quantity of seeds produced and entering the soil ensures that a large number of seeds still survive in deeper soil layers, even though Solidago seeds might not form a longterm persistent bank of viable seeds. Compared to invaded soils, Solidago abundance was far less in uninvaded soils at both $0-5 \mathrm{~cm}$ depth (mean per site $=3433 \pm 1936 \mathrm{~m}^{-2}$ ) and $5-10 \mathrm{~cm}$ depth $\left(468 \pm 307 \mathrm{~m}^{-2}\right)$, indicating that uninvaded areas were very likely to have been free of Solidago invasion, at least in the recent past. However, while Solidago can spread vegetatively via rhizomes, the presence of winddispersed seeds in uninvaded soils may lead to subsequent invasion if these soils undergo a high level of disturbance (Hartmann Schuldes, Kübler, \& Konold, 1995), even if Solidago has recently been removed completely from adjacent invaded areas.

\section{Conclusions}

In contrast with other well-studied invasive plant species, Solidago gigantea (and S. canadensis) has a limited impact on the native seed bank community when compared to neighbouring uninvaded areas. The idiosyncratic results observed suggest that growth conditions may be optimal for seed production (and therefore seed bank input) in invaded areas at some sites, and in uninvaded areas elsewhere. Variation in seed bank composition among sites was large, thus any effects of Solidago may depend heavily on environmental conditions underpinning initial 'uninvaded' species composition at a particular habitat. 


\section{Acknowledgements}

Thanks go to Dr. Veit Dörken (University of Konstanz) and Dr. Volker Hellmann, who helped with plant identification, and Otmar Ficht for experimental assistance. WD would like to thank the Deutsche Forschungsgemeinschaft (AZ DA 1502/1-1) for funding.

\section{References}

Bates, D., Maechler, M., Bolker, B., \& Walker, S. (2014). lme4: Linear mixed-effects models using Eigen and S4. R package version 1.0-6, http://CRAN.R-project.org/package=lme4

Clarke, K. R. (1993). Nonparametric multivariate analyses of changes in community structure. Australian Journal of Ecology, $18,117-143$.

Dassonville, N., Vanderhoeven, S., Vanparys, V., Hayez, M., Gruber, W., \& Meerts, P. (2008). Impacts of alien invasive plants on soil nutrients are correlated with initial site conditions in NW Europe. Oecologia, 157, 131-140.

Davis, M., Chew, M. K., Hobbs, R. J., Lugo, A. E., Ewel, J. J., Vermeij, G. J., et al. (2011). Don't judge species on their origins. Nature, 474, 153-154.

de Groot, M., Kleijn, D., \& Jogan, N. (2007). Species groups occupying different trophic levels respond differently to the invasion of semi-natural vegetation by Solidago canadensis. Biological Conservation, 136, 612-617.

del Fabbro, C., Güsewell, S., \& Prati, D. (2014). Allelopathic effects of three plant invaders on germination of native species: A field study. Biological Invasions, 16, 1035-1042.

Gioria, M., \& Osborne, B. (2010). Similarities in the impact of three large invasive plant species on soil seed bank communities. Biological Invasions, 12, 1671-1683.

Gioria, M., Pyšek, P., \& Moravcova, L. (2012). Soil seed banks in plant invasions: Promoting species invasiveness and long-term impact on plant community dynamics. Preslia, 84, 327-350.

Hartmann, E., Schuldes, H., Kübler, R., \& Konold, W. (1995). Neophyten: Biologie, Verbreitung und Kontrolle ausgewählter Arten. Landsberg: Ecomed.

Kuznetsova, A., Brockhodd, P. B., \& Christensen, R. H. B. (2013). ImerTest: Tests for random and fixed effects for linear mixed effect models (lmer objects of lme4 package). Version 2.0-6. $R$ package version 2.0-3, http://CRAN.Rproject.org/package=lmerTest.

Oksanen, J., Blanchet, F. G., Kindt, R., Legendre, P., Minchin, P. R., O'Hara, R. B., et al. (2013). vegan: Community Ecology Package. R package version 2.0-10, http://CRAN.Rproject.org/package=vegan.

R Core Team. (2013). R: A language and environment for statistical computing. Version 3.0.2. Vienna, Austria: R Foundation for Statistical Computing.

Scharfy, D., Eggenschwiler, H., Venterink, O. H., Edwards, P. J., \& Güsewell, S. (2009). The invasive alien plant species Solidago gigantea alters ecosystem properties across habitats with differing fertility. Journal of Vegetation Science, 20, 1072-1085.

Sebald, O., Seybold, S., Philippi, G., \& Woerz, A. (1996). Die Farnund Bluetenpflanzen Baden-Wuerttembergs. Band 6: Spezieller Teil (Spermatophyta, Unterklasse Asteridae) Valerianaceae bis Asteraceae. Stuttgart (Hohenheim): Verlag Eugen Ulmer.

Thompson, K., Bakker, J. P., \& Bekker, R. M. (1997). The soil seed banks of North West Europe: Methodology density and morphology. Cambridge, UK: Cambridge University Press.

Thompson, K., \& Grime, J. P. (1979). Seasonal-vartiation in the seed banks of herbaceous species in 10 contrasting habitats. Journal of Ecology, 67, 893-921.

Vila, M., Espinar, J. L., Hejda, M., Hulme, P. E., Jarošik, V., Maron, J. L., et al. (2011). Ecological impacts of invasive alien plants: A meta-analysis of their effects on species, communities and ecosystems. Ecology Letters, 14, 702-708.

Weber, E. (1998). The dynamics of plant invasions: A case study of three exotic goldenrod species (Solidago L.) in Europe. Journal of Biogeography, 25, 147-154.

Weber, E., \& Jakobs, G. (2005). Biological flora of central Europe: Solidago gigantea Aiton. Flora, 200, 109-118.

Werner, P. A., Bradbury, I. K., \& Gross, R. S. (1980). The biology of Canadian weeds. 45. Solidago canadensis L. Canadian Journal of Plant Science, 60, 1393-1409. 